\title{
Effect of cholecystokinin octapeptide on food intake in pigs
}

\author{
By B. A. Baldwin, T. R. Cooper and R. F. Parrott, ARC Institute of Animal
} Physiology, Babraham, Cambridge $C B_{2}{ }_{4} A T$

Considerable interest has been aroused by the suggestion that the gut hormone cholecystokinin $(\mathrm{CCK})$ is released during feeding and then acts as a satiety signal (Gibbs et al. 1973). Many studies, in species ranging from the mouse to man, have shown that peripheral administration of CCK, or its octapeptide, will reduce food intake. However, inhibition of feeding could be produced via a satiety system specific to food or by a transient malaise affecting all motivated behaviours. In the rat, CCK induces behaviour resembling that seen during normal satiety (Antin et al. 1975) and does not affect drinking in thirsty animals (Gibbs et al. 1973). Using rats, some workers have been able to produce avoidance of a novel food whose presentation was paired with CCK administration (Deutsch \& Hardy, 1977) and such 'bait-shyness' is indicative of illness. By contrast, others have been unable to demonstrate this effect either in rats (Gibbset al. 1973) or rabbits (Houpt et al. I 978). In man, although slow intravenous infusion of CCK does not cause marked side-effects, the authors state that 'some individuals may have experienced discomfort' (Kissileff et al. 1981) and high doses cause nausea (Sturdevant \& Goetz, I976). It appears that, in some species, administration of CCK may cause transient malaise and that tests using non-food reinforcers may help to clarify the situation.

Intravenously administered CCK reduces consummatory food intake in the 4-hour fasted pig (Anika et al. I98I) and the present study extends these observations using operant techniques developed in this laboratory for the pig. We have investigated the effect on operant feeding of intravenous injection of CCK octapeptide and have compared this with effects on operant drinking of water or sucrose solution and on operant responding for radiant heat.

\section{Methods}

Prepubertal male and female Large White pigs were trained to press a panel with their snouts to obtain food or other reinforcers. The pigs had to press a fixed number of times before the food was delivered and were thus on a 'Fixed Ratio' (FR) schedule of reinforcement. The animals were surgically prepared with jugular vein catheters which were regularly flushed with heparinized saline. In all experiments the treatments were, 0 (control), I0, 20 or 40 units $/ \mathrm{kg}$ CCK octapeptide (Cambridge Research Biochemicals) given in about $5 \mathrm{ml}$ saline $(9 \mathrm{~g}$ $\mathrm{NaCl} / 1$ ) and washed in with a similar volume. Injections were given by hand and took about $30 \mathrm{~s}$. Each animal received one test/d and all treatments were given twice. Reinforcements obtained were recorded on event and cumulative recorders. The mean number of reinforcements delivered in each 5 min (Expts 1,3 and 4 ) or 
Table I. Effect of increasing intravenous doses of CCK octapeptide on operant responding by pigs for various reinforcers

(Values are the mean number of reinforcements obtained with their standard errors during the periods immediately preceding and following each injection)

\begin{tabular}{|c|c|c|c|c|c|c|c|c|}
\hline \multirow{2}{*}{$\begin{array}{c}\text { CCK } \\
\text { (units/ } \\
\text { kg) }\end{array}$} & \multicolumn{2}{|c|}{$\begin{array}{c}\text { Food } \\
\text { (reinforcements/ } \\
5 \mathrm{~min} \text { ) }\end{array}$} & \multicolumn{2}{|c|}{$\begin{array}{c}\text { Water } \\
\text { (reinforcements/ } \\
2 \text { min) }\end{array}$} & \multicolumn{2}{|c|}{$\begin{array}{c}\text { Sucrose } \\
\text { (reinforcements/ } \\
5 \mathrm{~min} \text { ) }\end{array}$} & \multicolumn{2}{|c|}{$\begin{array}{c}\text { Heat } \\
\text { (reinforcements/ } \\
5 \mathrm{~min} \text { ) }\end{array}$} \\
\hline & $\begin{array}{l}\text { Before } \\
\text { treatment }\end{array}$ & $\begin{array}{c}\text { After } \\
\text { treatment }\end{array}$ & $\begin{array}{c}\text { Before } \\
\text { treatment }\end{array}$ & $\begin{array}{c}\text { After } \\
\text { treatment }\end{array}$ & $\begin{array}{l}\text { Before } \\
\text { treatment }\end{array}$ & $\begin{array}{c}\text { After } \\
\text { treatment }\end{array}$ & $\begin{array}{l}\text { Before } \\
\text { treatment }\end{array}$ & $\begin{array}{c}\text { After } \\
\text { treatment }\end{array}$ \\
\hline 0 & $\begin{array}{r}\text { II } 8 \\
+1.0\end{array}$ & $\begin{array}{l}12 \cdot 1 \\
+0.9\end{array}$ & $\begin{array}{r}\text { I6. } \\
+\mathrm{I} \cdot 2\end{array}$ & $\begin{array}{r}14.2 \\
+2.5\end{array}$ & $\begin{array}{l}46 \cdot 1 \\
+6 \cdot I\end{array}$ & $\begin{array}{r}43.6 \\
+6.0\end{array}$ & $\begin{array}{r}38 \cdot 2 \\
+0.9\end{array}$ & $\begin{array}{l}3^{8 \cdot 0} \\
+2 \cdot 1\end{array}$ \\
\hline IO & $\begin{array}{r}16 \cdot 5 \\
\pm 1 \cdot 0\end{array}$ & $\begin{array}{r}14.8 \\
+2.6\end{array}$ & $\begin{array}{r}15.4 \\
+2.6\end{array}$ & $\begin{array}{r}4.0 \\
+2 \cdot 5\end{array}$ & $\begin{array}{r}43 \cdot 5 \\
\pm 6 \cdot 4\end{array}$ & $\begin{array}{r}30 \cdot 1 \\
\pm 5 \cdot 1\end{array}$ & $\begin{array}{r}3^{8} \cdot 5 \\
+1 \cdot 7\end{array}$ & $\begin{array}{r}39.4 \\
+1.8\end{array}$ \\
\hline 20 & $\begin{array}{r}147 \\
+1.2\end{array}$ & $\begin{array}{l}\text { I } 2 \cdot I * * \\
\pm \mathrm{I} \cdot 4\end{array}$ & $\begin{array}{r}14.9 \\
+1.9\end{array}$ & $\begin{aligned} & 1 \cdot 3^{* *} \\
\pm & 0.9\end{aligned}$ & $\begin{array}{r}45.1 \\
\pm 3.6\end{array}$ & $\begin{array}{l}25.4^{* *} \\
\pm 5.9\end{array}$ & $\begin{array}{l}39 \cdot 2 \\
\pm I I \cdot I\end{array}$ & $\begin{array}{l}3^{8} \cdot 5 \\
+\mathrm{I} \cdot 6\end{array}$ \\
\hline $4^{\circ}$ & $\begin{array}{r}10.7 \\
\pm 0.6\end{array}$ & $\begin{aligned} & 2.0^{* * * *} \\
&+0.5\end{aligned}$ & $\begin{array}{r}18.8 \\
+3.5\end{array}$ & $\begin{array}{l}0.0^{\prime * *} \\
\pm 0.0\end{array}$ & $\begin{array}{r}448 \\
+5.8\end{array}$ & $\begin{array}{l}18 \cdot 0^{\prime * *} \\
\pm 2 \cdot 2\end{array}$ & $\begin{array}{r}4 \mathrm{I} \cdot \mathrm{I} \\
\pm 0.8\end{array}$ & $\begin{array}{r}36 \cdot 3 \\
\pm 4 \cdot 9\end{array}$ \\
\hline
\end{tabular}

Statistical significance of difference from values before treatment: "* $P<0.02,{ }^{* * *} P<0.00 \mathrm{r}$.

2 min (Expt 2) period were calculated. Statistical comparisons were made between the periods immediately preceding and following the injection, using the paired $t$ test (two-tailed).

\section{Results}

Expt $\mathrm{I}$. Effect on responding for food. Six young pigs were trained to work for $2 \mathrm{~g}$ reinforcements of pelleted food on FR 20 for a $45 \mathrm{~min}$ period following $23 \mathrm{~h}$ without food. Injections were given 15 min after feeding commenced.

Feeding was not affected following injection of saline $(9 \mathrm{~g} \mathrm{NaCl} / 1)$ or 10 units $/ \mathrm{kg}$ of CCK but was disrupted immediately after administration of the 20 or 40 unit dose (Table I). However, the effect of CCK was short-lived and the pigs soon resumed a normal rate of panel pressing for food.

Expt 2. Effect on responding for water. Four pigs worked for $10 \mathrm{ml}$ reinforcements of water on FR 5 for $\mathrm{I} 2$ min following a $17 \mathrm{~h}$ period of water deprivation. Injections were given 2 min after they started to press the panel.

Saline had no effect on water intake. However, operant responding for water was reduced following administration of all doses of CCK (Table I). The effect of ro units of $\mathrm{CCK}$ was not significant because of the small number of animals used.

Expt 3. Effect on responding for sucrose solutions. Five pigs worked for $10 \mathrm{ml}$ reinforcements of $0.25 \mathrm{M}$-sucrose solution on FR 5 . The pigs were fed and watered before the experiments. The animals were tested over a $35 \mathrm{~min}$ period and the injections were given after $5 \mathrm{~min}$ had elapsed.

After the saline injection pigs worked consistently for at least $10 \mathrm{~min}$. However, the 20 and 40 unit doses of CCK significantly reduced operant responding during the $5 \mathrm{~min}$ period immediately following the injection (Table $\mathrm{I}$ ). 
Expt 4. Effect on responding for heat. Six pigs were trained to press a panel to obtain $5 \mathrm{~s}$ bursts of infra-red heat from $3 \times 275 \mathrm{~W}$ infra-red bulbs. Tests were carried out in a temperature-controlled room maintained at $0^{\circ}$. The pigs were allowed to work for $15 \mathrm{~min}$ and then they were removed from the room, injected, and returned to work for heat for a further $30 \mathrm{~min}$.

The injection procedure did not affect subsequent responding, as indicated by the lack of effect of saline treatment (Table I). Moreover, no dose of CCK had any effect on the response pattern, although there was a suggestion of a decrease in the 5 min period immediately following administration of the 40 unit dose (Table I).

\section{Discussion}

The higher doses of CCK not only reduced food intake but also the amount of water or sucrose obtained in the post injection period and this indicates that the inhibiting effect is not specific to food intake. It was also found that the effects of intravenous $\mathrm{CCK}$ were transient and the pigs later resumed responding for food, water or sucrose. This behaviour does not resemble normal satiety.

The lack of effect on responding for heat may be due to the fact that the pigs only had to press once to obtain a burst of radiant heat lasting several seconds and a transient reduction in their rate of panel pressing will cause a marked decrease in the number of reinforcements obtained.

The use of operant methods in which animals work for a variety of reinforcers promises to be useful in the evaluation of the specificity of putative satiety agents.

REFERENCES

Anika, S. M., Houpt, T. R. \& Houpt, K. A. (198I). Am. F. Physiol. 240, 310.

Antin, J., Gibbs, J., Holt, J., Young, R. C. \& Smith, G. P. (1975). J. Comp. Physiol. Psychol. 89, 784 .

Deutsch, J. A. \& Hardy, W. T. (1977). Nature, Lond. 266, 196.

Gibbs, J., Young, R. C. \& Smith, G. P. (1973). F. Comp. Physiol. Psychol. 84, 488.

Houpt, T. R., Anika, S. M. \& Wolft, N. C. (1978). Am. F. Physiol. 235, 23.

Kissileff, H. R., Pi-Sunyer, F. X., Thornton, J. \& Smith, G. P. (1981). Am. f. clin. Nutr. 34, 154.

Sturdevant, R. A. L. \& Goetz, H. (1976). Nature, Lond. 261, 713. 